\title{
UNIVERSITY LIFE AND AUSTRALIAN HOMES: THREE CASE STUDIES OF INTERNATIONAL MUSLIM STUDENTS IN BRISBANE
}

Zulkeplee Othman

Laurie Buys

Rosemary Aird

\author{
PhD Candidate, \\ Queensland University of Technology, Brisbane, Australia, \\ School of Design, Faculty of Creative Industries. \\ email: zul.othman@student.qut.edu.au
}

Professor,

Queensland University of Technology, Brisbane, Australia, School of Design, Faculty of Creative Industries.

email: I.buys@qut.edu.au

Senior Research Associate,

Queensland University of Technology, Brisbane, Australia, School of Design, Faculty of Creative Industries.

email: r.aird@qut.edu.au

Received: July $25^{\text {th }} 2014$; Accepted: October 29 2014 ; Available Online: December $15^{\text {th }} 2014$

\begin{abstract}
Despite a significant increase in enrolments of postgraduate international Muslim students within Australian universities, little is known about their perceptions of life within Australian homes while undertaking their studies. The aim of this study is to investigate the ways in which students' cultural and religious traditions affect their use of domestic spaces within the homes in which they reside. The research found that participants faced some minor difficulties in achieving privacy, maintaining modesty and extending hospitality while able to perform their daily activities in Australian designed homes. The findings suggest that greater research attention needs to be given to the development of Australian home designs that are adaptable to the needs of a multicultural society. Australian society encompasses diverse cultural customs and requirements with respect to home design, and these are yet to be explored.
\end{abstract}

Keywords: Australia; university students; home; Islam; privacy; modesty; hospitality

\begin{abstract}
Abstrak
Pendaftaran mahasiswa Muslim internasional pascasarjana di universitas-universitas Australia, mengalami peningkatan yang sangat signifikan. Sedikit sekali pembahasan tentang persepsi mahasiswa muslim pada saat melakukan studi dan tinggal di Australia. Tujuan dari penelitian ini adalah untuk menyelidiki cara-cara dimana tradisi budaya dan keagamaan siswa mempengaruhi penggunaan ruang domestik di mana mereka tinggal. Hasil kajian membuktikan bahwa mahasiswa Muslim di Australia menghadapi kesulitan mencapai privasi, menjaga kesopanan dan keramahan, dalam melakukan kegiatan sehari-hari mereka di rumah yang mereka tempati di Australia. Hasil kajian juga menunjukkan perlunya dikembangkan dan dieksplorasi desain rumah Australia yang dapat disesuaikan dengan kebutuhan masyarakat multikultural, dengan adat dan budaya yang beragam.
\end{abstract}

Kata kunci: Australia; mahasiswa; rumah; Islam; privasi; kesopanan; keramahan

\section{Internationalisation of tertiary education in Australia}

Tertiary education plays an important role in establishing the development of economic, social, cultural intellects and quality of life for those living in contemporary society [1]. The rapid growth of enrolment of international students through internationalisation of tertiary education in Australia has contributed in the nation's financial stability, economic growth as well as cultural diversity [2] [3] [4]. There are 366,914 student visa holders within Australia as of 31 March 2014 , representing in an increase of $10.4 \%$ from 2013 , with $60.8 \%$ being higher education visas [5]. Student visa holders were predominantly from China (21\%), India (11.1\%) and South Korea (4.5\%) 
but there was also a significant increase in the number of postgraduate international Muslim students, mostly from countries like Malaysia, Indonesia, Pakistan, Saudi Arabia, Iraq, Iran, Bangladesh and Libya [5].

Studying abroad, especially at tertiary level, brings significant benefits to a student [6] [7]. An obvious reason for pursuing tertiary education overseas is to learn and to experience cultural diversity at a university, which may not be available from the students' countries of origin [8]. University life in a foreign country provides an opportunity for an international student to live independently, and manage his/her own finance, lifestyle, personality and environment [4] [7] [9]. Studying abroad offers opportunities of promoting creative cognition and creative thinking through campus intercultural societies [10] [11]. As for non-English speaking background or 'English as a second language' students, studying in an English speaking country, such as Australia, provides an excellent opportunity for them to improve their English and create invaluable social networks and future international job prospects [12]. While some students may plan to work and live overseas permanently, most intend to take home what they have learnt from overseas and apply it to their working environment in their country of origin. Another advantage of studying abroad is that it provides students the opportunity to introduce their own culture to others while simultaneously becoming an inter-culturally competent person [13].

\section{Meaning of 'home' for international Muslim students}

A home is conceived to be a place where an individual feels protected, safe, and secure and surrounded by family, siblings, close friends, siblings and memorable belongings [14] [15]. The meaning of 'home' for an international student may refer to a temporary living situation. It may be a place to experience an international life within a safe context in a different geographical location from their home countries. It is therefore important for international student accommodation to provide students with as much comfort as possible for the duration of their studies [16]. Yet, life abroad has the potential to cause isolation, homesickness and 'cultural loneliness' because of the absence of students' familiar cultures and lifestyles [17]. In the case of an international Muslim student studying in a predominantly non-Muslim country like Australia, this feeling of homesickness and alienation can become more apparent than it is for other nonMuslim students [18] [19]. Major cultural differences between Islamic traditions and Australian western ways of life can present a serious 'culture-shock' to these students [18] [19]. These feelings of isolation and the loss of sense of belonging may affect their studies and cause dissatisfaction among these students [18].

Many of the social interactions among Australian and other western international students involve various activities that are alcoholrelated, and this type of social interaction is unappealing to Muslim students, thereby excluding them from participation in these activities [8] [11] [18]. This is one of the main causes of social marginalisation and disadvantage among this group, especially in the case of female international Muslim students [8] [18] [28]. Consequently, most of these students create their own social networks with other local and international Muslims students and conduct their social activities with other Muslim students who have similar interests [19]. The majority of married international Muslim postgraduate students who receive scholarships or other types of funding have the advantage of bringing their families to live temporarily in Australia while undertaking their studies [19]. In the case of both singles and married couples, 'student' homes become one of the most important, safe and familiar domains for these students to socialise and interact with their friends and families after their study hours [19].

\section{Australia: A different country with different home styles}

Finding an ideal home to live in can be the most challenging task for an international student studying in Australia [16]. There are several factors that need to be considered when looking for a suitable home such as cost of rentals, distance from home to university, and access to other amenities such as shopping malls, gymnasiums and places of worship [16, 18]. Furthermore, there are different types of accommodation available for international students, including student villages, homestays with Australian families or even private and independent homes, townhouses or apartments [16, 20].

While research attention has been given to international students' levels of satisfaction towards housing and university accommodation services provided for them in recent years [3, 16, $18]$, there is a paucity of research focusing on international Muslim students' perceptions of living within an Australian home and its impact upon their Islamic domestic lifestyle and use of space. These perceptions may influence their levels of satisfaction, student life experiences and academic performance while living in Australia. Moreover, the designs and layouts of these homes may contradict international Muslim students' religious and cultural traditions with regards to their home environments.

Islamic domestic principles are mainly derived from Sharia: the Islamic moral codes and guidelines derived from Quran (the revelations of Allah to Prophet Muhammad), sunnas and hadiths (utterances and actions of Prophet Muhammad) 
[21] [22]. Islamic domestic guidelines from Sharia involve three main principles in home designs, including the need for:

a. Privacy

a safe and peaceful sanctuary for a Muslim student and his/her family;

b. Modesty

a place for personal and family religious activities or education, further defined by humility in design through design simplicity and frugality;

c. Hospitality

a base for entertaining guests and strengthening relationships with society [21] [22].

\section{Privacy, modesty and hospitality in Muslim homes}

Traditional Muslim homes in the Middle East strictly follow Islamic principles of privacy, modesty, hospitality as well as careful design considerations on climatic factors that determine the spatial designs and facades of the dwellings. The following discusses on the design implications from the influence of these principles in home designs in two different zones of Muslim countries, the Middle East and South East Asia (Malaysia and Indonesia).

\section{Traditional Muslim homes in Middle East}

Privacy in traditional Middle Eastern homes, involves three clearly defined layers of privacies: a) privacy between outsiders and neighbours, b) privacy between males and females, and c) privacy between family members and relatives inside a home [23]. In order to control the privacy and safety of the female members of the family, visual privacy is the primary design factor that affects the layout and use of spaces of a Muslim home [24]. Some of the design interventions include the intervention of internal courtyards, gender segregated space planning, similar building heights, balconies and rooftop terraces, placement and the sizes of windows and openings, and careful location of entrance doors [21] [25] [26]. The control of sound transmission from the outside into internal spaces is another main design criterion to achieve privacy in these homes. Acoustic privacy is normally achieved through the use of thick walls, floors and roofs [21]. Apart from visual and acoustic privacies, [27] highlight that maintaining olfactory privacy through the use of incense can prevent or at least reduce any contaminated smell from the kitchen from spreading to guest spaces in Arab-Gulf homes [27].

Modesty (haya in Arabic) is a significant attribute or a demeanour that portrays a person's humility and moderation through their behaviours and actions [29] [30]. There are two main categories in the classification of modesty behaviours: a) physical modesty: dress code; and b) inner modesty: internal perception (selfimprovement or self-motivation) and social interaction (shyness, humble and politeness) [21] [30]. Islamic concept of modesty with regards to housing, on the other hand, emphasises two basic design categories: a) domestic spaces for religious activities and education; and b) balance of neighbourhood wealth through frugal design approaches while avoiding transgression and haughtiness such as wastefulness and showing off one's wealth [21] [22]. It is essential to have a space for religious activities or education in a Muslim home such as reading and reciting of Quran [22]. Such activities can be performed either in one of the bedrooms, living rooms or in dedicated rooms or spaces with careful considerations of qiblah directions (facing towards Mecca) [22]. It is an important measure for these spaces to have easy access to toilets for cleansing or ablution prior to performing the prayers or reciting Quran. One of the common practices in Muslim countries in the Middle East is the use of Islamic handheld bidet hose or shattaf in wet areas of the toilet according to Islamic toilet etiquette and hygienical jurisprudence.

Hospitality can be defined as a benevolent demeanour and commiserative behaviours towards strangers and others [27] [31] [32]. Extending hospitality in Islam represents a person's generosity and receptiveness to others and accordingly, such hospitality is integrated in his/her private domestic domains. This friendly behaviour further influences the designs, layouts and use of spaces of a Muslim home. The public domain of the house in the Middle Eastern home is the entertainment space for male guests, which is called a majlis [31]. It symbolises honour and masculinity of a Muslim host to the guests and this is the only segment of the house that is accessible directly from the main entrance or the main street [27] [31]. Female entertainment spaces in the Middle Eastern homes are located exclusively in a private room located inside the house, commonly with another separate entrance [27]. This female salon is decorated with elegant modern décor and not visible from the men's majlis [31]. The salon allows female guests to socialise with their female hosts, exchange ideas or display their recent garments, fragrance or cosmetic items privately, without the presence of male guests and family members [27].

\section{Traditional houses in Malaysia and Indonesia}

Traditional Malay houses in Malaysia, in contrast to the Middle Eastern homes, emphasise in community and kinship strength over family's privacy [33]. The guest space or serambi in traditional Malay is the largest section located at the front, spacious enough for activities like discussions, meetings, congregational prayers and family's funerary services [33] [34]. In traditional Malay houses in Malaysia, women socialise in selang (transition space) and rumah tengah (middle 
room) while food is prepared in dapur (kitchen) at the back section of the house [33] [34]. It is not an absolute requirement in traditional Malay homes to segregate men and women. Women are commonly involved in assisting in handing out food to guests at interval times when required but retreat back to the middle and back sections of the house to continue their activities [33]. Each of the 13 states in Malaysia has their own unique styles and forms of vernacular architecture while following the general spatial concepts of a Malay house, with the exception of traditional houses in Sabah and Sarawak.

Traditional Indonesian houses are comprised of 33 different provinces that form their own vernacular styles or rumah adat [35]. Traditional Achenese houses for example, has similar "house on the stilts" concept with the Malay houses in Malaysia but divided into three vertical sections: a) bottom section (underworld) - children's play or yup rumah; b) middle section (middle world) generally three rooms: the front porch (seuramoukeu), main section or living room (seuramou teungoh or rumah inong) and the back porch (seuramou likot) with additional kitchen wing (dapu) and; c) upper section (upper world) - loft [35] [36] [37]. The bottom section or yup rumah is built high enough for children's play area or for women to produce their traditional arts and crafts [35] [37]. The front porch of the middle section is the common area to receive guests and teaching and learning of Quran (taklim) [35] [37]. The main section, seuramou teungoh or rumoh inong, acts as the core of the house and is considered sacred and private section of the house and bedrooms for female members of the family [35] [37]. The back section or seuramou likot, usually located on the East, is the section where family eating and dining takes place. An additional kitchen wing (dapu) is built to allow additional kitchen space for women [35] [37]. The upper section is normally a loft served a family's storage area [35] [37]. It is a common tradition in Acehnese house that the owner of the home is the female member of the family - the wife or the married daughter [36]. There are other similar traditional houses in different provinces such as in Riau Islands, Jakarta and Lampung that possess similar architectural style with the Malaysian traditional houses [35] [36].

Applying humility in a home design encourages a person to control his/her financial budget without compromising his/her perceptions of an ideal or dream home for the family. This is demonstrated in the use of locally available materials in the construction of traditional Malay and Acehnese homes in Malaysia and Indonesia. Palm or coconut leaves are used for roof materials, providing both thermal comfort and a waterproofing mechanism to suit the Malaysian and Indonesian humid climatic conditions [33] [35] [37]. The timber walls are craftily engraved with floral themes to reflect Islamic decorative styles and motives [33] [35] [37]. The concepts of beautification and decoration to enhance the quality of home using affordable materials and fastidious furniture arrangements are encouraged in Islam [21] [22]. This intent should not lead to any negative impacts to the guests through repulsive or haughty behaviours [22]. Excessive waste and spending that embody hedonistic and materialistic tendencies are prohibited in Islam [21] [22].

Islamic teachings on privacy, modesty and hospitality strongly regulate Muslim activities, behaviours and the use of their domestic spaces. The three design principles possess their own unique qualities but sometimes are often misapprehended by non-Muslims [21] [27] [31]. Furthermore, Muslims living in different countries follow their own cultural traditions with regards to home privacy, modesty and hospitality despite similar Islamic religious teachings. In Australia for example, the Muslim population is a mixture of more than seventy countries of origin [38]. This mixed population brings and practices their cultural and religious traditions when they settle in the country. Australian homes are built to follow the national and local building codes, climatic conditions and Australian architectural styles and movements, unless specifically designed and built by Muslim architects or designers. Houses in Brisbane, Queensland, for example, are designed to follow the extroverted verandah lifestyle within a sub-tropical climate. The main objective of this paper is to investigate how international Muslim students in Brisbane perceive and achieve privacy, modesty and hospitality within their Australian designed homes, and how these affect their use of domestic spaces, furniture arrangements and satisfaction levels of their current homes.

\section{Methodology}

Data were gathered from three case studies of international postgraduate Muslim students currently undertaking their final year studies at the same university and living in three different suburbs in Brisbane. As a capital city of the state of Queensland and the most populous city, Brisbane has a rapid growing of Muslim population [38]. All participants have lived in Australia for at least three years and currently living in shared, rented properties. Face-to-face semi-structured interviews were conducted (lasting between 60 to 90 minutes) using semi-structured questions, observations and photographs of their homes. Observation was included as part of data collection to obtain visual data related to participants' behaviours within their domestic settings. Participants were recruited through the university's Islamic organizations. All participants are married and aged between 30 and 40 years. Pseudonyms are used to assure confidentiality and anonymity of the information gathered from all 
individuals. A summary of demographic characteristics of householders is shown in Table 1.

Table 1. Summary of the three case studies

\begin{tabular}{lllllll}
\hline PARTICIPANT & GENDER & HOUSE TYPE & $\begin{array}{l}\text { NO. OF } \\
\text { ROOMS }\end{array}$ & $\begin{array}{l}\text { NO. OF } \\
\text { HOUSEHOLD } \\
\text { AT HOME }\end{array}$ & $\begin{array}{l}\text { ETHNIC } \\
\text { BACKGROUND }\end{array}$ & $\begin{array}{l}\text { STUDY } \\
\text { COURSE }\end{array}$ \\
\hline Dewi & $\mathrm{F}$ & $\begin{array}{l}\text { Detached } \\
\text { Home }\end{array}$ & 4 & $\begin{array}{l}7 \text { (4 adults, } \\
3 \text { children) }\end{array}$ & Indonesian & PhD \\
\hline Soraya & $\mathrm{F}$ & Townhouse & 2 & 3 & Iranian & MA \\
\hline Farid & $M$ & Apartment & 2 & 3 & Iranian & PhD \\
\hline
\end{tabular}

Source: Author

\section{Case Study 1: Description}

The home that Dewi lives in is a timber Queensland house located in a leafy suburb approximately five kilometres from Brisbane city centre. Dewi is married to Adam and both come from Indonesia. Dewi is a PhD student while Adam is working part time as a taxi driver in Brisbane. He is a qualified architect in Indonesia. Dewi and Adam have two of their children living with them at the moment while their youngest daughter lives with Dewi's parents in Indonesia. In Brisbane, they live with another non-Muslim Indonesian family. The non-Muslim family is made up of Andy who is another postgraduate student of the same university, and Andy's wife and son. Dewi's landlord owns a few houses around Brisbane and specializes in leasing them to Indonesian students in Brisbane. An extension at the rear section of Dewi's home was added to accommodate a new guest bedroom and office (Figure 1). The house is built on timber stumps and there is enough height at the back section to allow for storage, laundry and drying areas underneath the house because of the sloped land. Dewi's home has a spacious back yard with shady trees and shrubs. The back area is used mainly as a children's playground area.

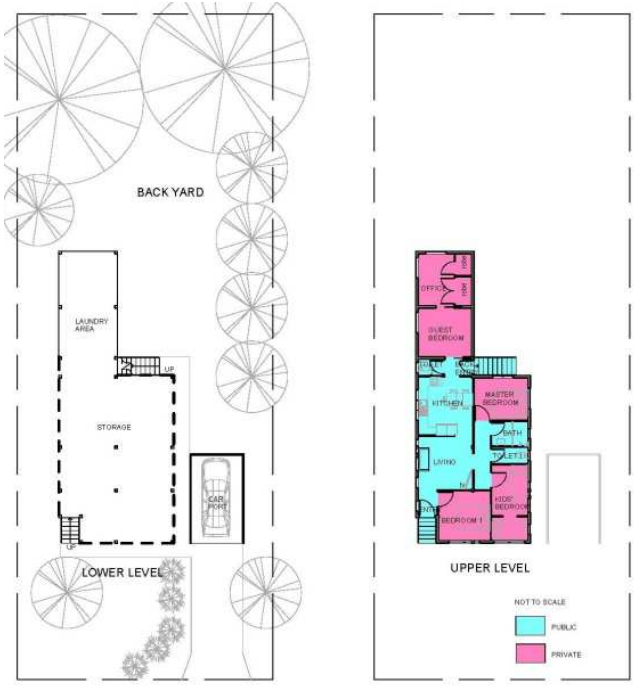

Figure 1. Floor plans of Dewi's home (Source: Zul Othman, Author)

\section{Case Study 2: Description}

Soraya's home is a two-level, two-bedroom brick townhouse only two kilometres away from Brisbane city centre. It is built in one of the oldest and quietest residential suburbs in Brisbane and is close to the university. Soraya is a Masters student from Iran and recently married to James, an Australian. Both Soraya and James occupy the upper level of the townhouse (Figure 2) while the room downstairs is leased to another house mate, Jacob, who is working in Brisbane. James works 300 kilometres outside of Brisbane city centre and spends most of his time in his employer's apartment unit in South West Queensland which is close to his office. He returns home every fortnight to spend his leave time with Soraya.

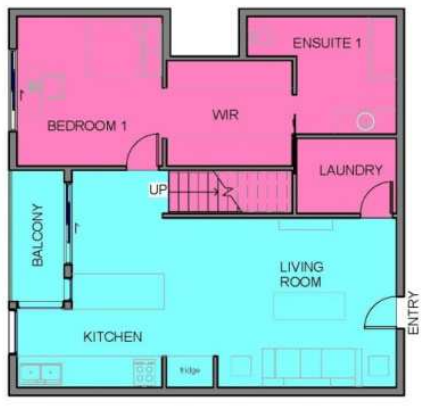

LOWER LEVEL

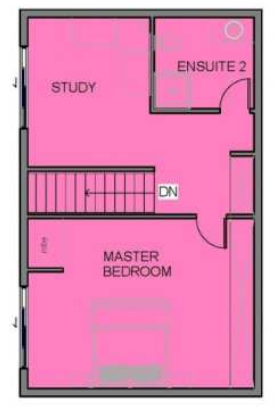

UPPER LEVEL

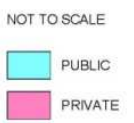

Figure 2. Floor plans of Soraya's home (Source: Zul Othman, Author)

\section{Case Study 3: Description}

Farid is an Iranian student and recently married. He lives in a two-bedroom unit with his wife Henna and another Iranian PhD student housemate, Ehsan. They decided to rent the unit because of its close location to the main shopping centre and other amenities as well as its location within an adequate travel distance to the university (seven kilometres to Brisbane city centre). Although Farid and Henna do not have any children, they receive regular visits from their 
other Iranian friends. Farid is highly involved with the university's Iranian students' association and often, some of their committee meetings and social gatherings are held at his home. The apartment unit has a living area, a laundry room and a small balcony, as shown in Figure 3. Farid converted the dining space to a study area since Farid, Henna and Ehsan are all full time students.

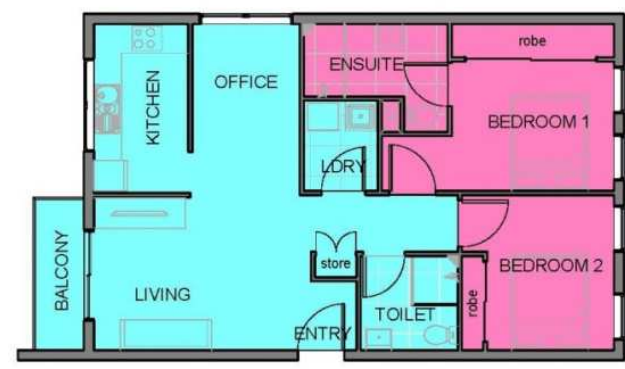

FLOOR PLAN

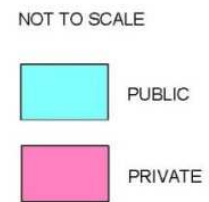

Figure 3. Floor plan of Farid's home (Source: Zul Othman, Author)

\section{Results}

All three participants value the significance of this study in providing insight into Muslim's' use of domestic spaces within western or non-Muslim environments. Each case study provides information gleaned from participants about their perceptions of their lived experience in Australian rented homes with respect to the three fundamental Islamic principles of privacy, modesty and hospitality.

\section{Case Study 1 Privacy}

Dewi wears her hijab (veil) outside and inside of her home. This is due to the fact that she shares the house with a non-Muslim Indonesian, Andy and his family.

"I have to wear my veil all the time, except in my room. If I have to check the rice or kettle in the kitchen, I have to wear my veil too. There is another friend that lives in a shared house with the same experience, and it is a concern for her as well. But I don't mind, I just wear it. But when they (other family) go out, I can take it off. Another concern for Dewi is being seen by the next door neighbor through kitchen windows while she is cooking and preparing for food (Figure 4)".

“I don't really like this house because if I don't wear the veil in the kitchen, somebody from the house next door can still see me. If I want to go to the kitchen, I still have to use my veil because of that. The other windows are fine because they are frosted glass. The kitchen windows are just clear glass".

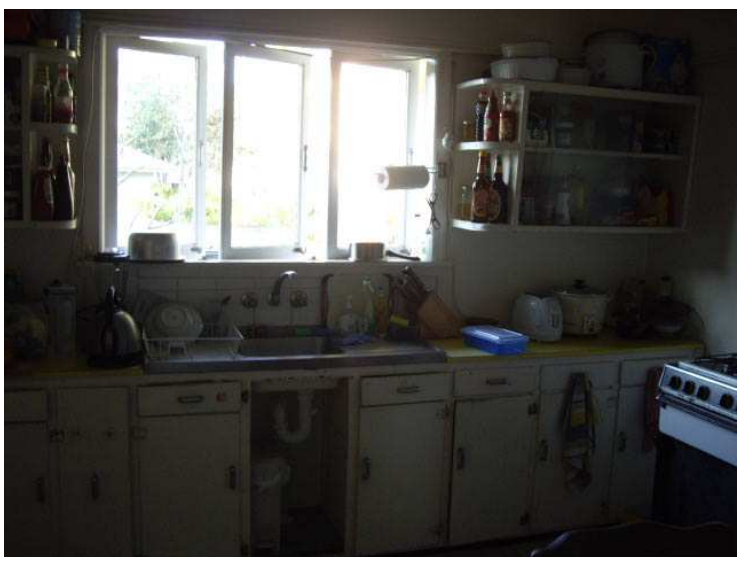

Figure 4. Kitchen windows at Dewi's home (Source: Zul Othman, Author)

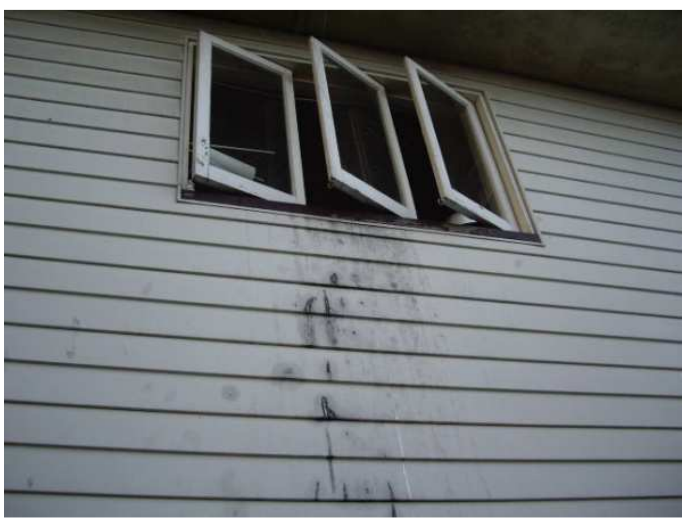

Figure 4. Kitchen windows at Dewi's home (Source: Zul Othman, Author)

Nonetheless, Dewi is lenient when it comes to gendered space. Although there are separate entrances for each family (front entrance for Andy's family and back entrance for Dewi's family) (Figures 1 and 5), Dewi explains that they share the same living room to watch television or socialize:

"There is no separate living rooms, just separate rooms for ourselves and the kids. There are also no separate entrances between males and females, just separate entrances for the other family. I'm not too strict with gender segregation. I used to be strict but then I read a lot and discussed a lot about it with others and I became more tolerant".

Despite the visibility problem with the kitchen windows (Figure 4), the level of visual privacy of frontage of Dewi's home, overall, is satisfactory. The front windows are outfitted with privacy screen louvres (Figure 6) to protect them from line of vision from the main street. Additionally, adequate landscaping in the back yard and side fences provide enough visual protection from the adjacent neighbours, as shown in Figure 6. 


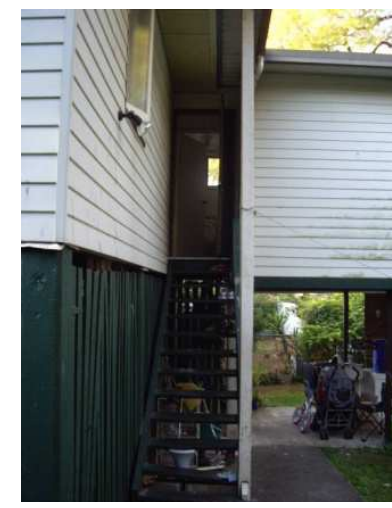

Figure 5. Front entry (Andy's entrance) and back entry (Dewi's entrance) (Source: Zul Othman, Author)

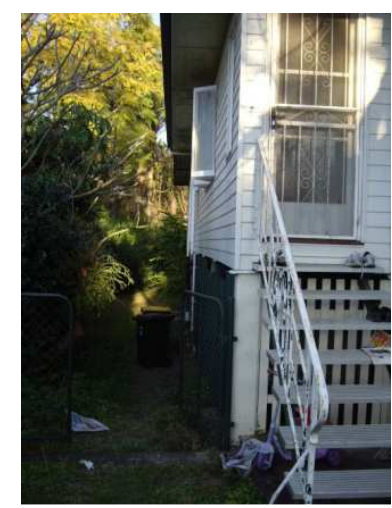

Figure 5. Front entry (Andy's entrance) and back entry (Dewi's entrance) (Source: Zul Othman, Author)

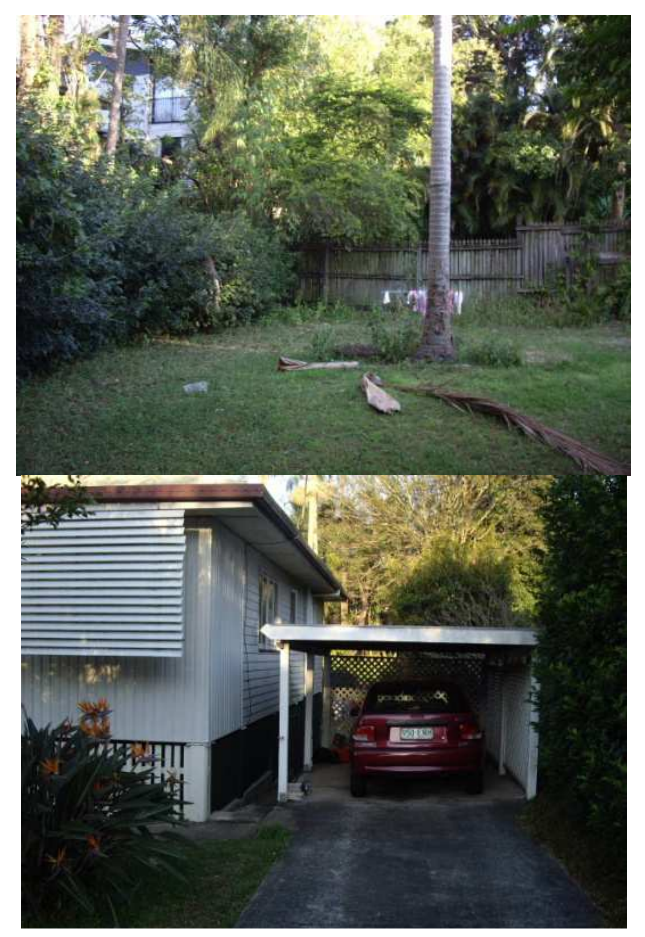

Figure 6. Back yard landscaping and privacy screens (Source: Zul Othman, Author)

\section{Modesty}

Dewi identifies herself as a religious Muslim. Her children perform regular congregational prayers with Adam and herself. However, they face the problem of having adequate spaces to conduct congregational prayers in the master bedroom:

"When we perform jamaah (prayers together), we have to make use of the available space. Ideally, my husband will be at front, and then my son will pray slightly behind him, next to him, and then the female at the back. But we can't do that because of limited space. So, my husband will be at the front to lead the prayers, and then the three of us will follow at the back".

Other modesty activities at home such as reciting the Quran or listening to the azan (call for prayer) are limited to Dewi's master bedroom:

"I just have to make sure that I'm not too noisy when I am reciting the Quran or play the azan in the laptop. In Indonesia, I can recite it as loud as possible. Here, I just have to make sure that my housemate is not disturbed".

Another common quandary with Dewi and her family is the use of water in toilets for cleansing and ablution. Dewi finds it difficult for herself and family to adapt to the typical 'dry' toilets in Australian homes as compared to the 'wet' toilets in her home in Indonesia. The separate toilet and bathroom arrangement (Figure 1) makes it more difficult for her to follow Islamic hygienical jurisprudence:

'I don't like is the toilet because it is different than our normal habit in Muslim community. We normally use water rather than toilet papers, so the design is not compatible. We have shattaf (Islamic handheld bidet hose/pipe) back home in Indonesia. The other concern about water use is that my landlord gave me notification that my water usage was twice as compared to other families".

With regards to design humility, Dewi adores the simple architectural treatments of the elevation of the house:

"I really like this house's architectural style and I plan to have this similar kind of house in Indonesia. What I like is the minimalist style. It's just simple without too much ornamentation".

\section{Hospitality}

In consideration of Dewi undertaking full time studies at the university while Adam leaves home for work at early hours, both hardly find any time to extend their hospitality to friends and guests. Dewi's only main guests are her children's friends, who sometimes spend some time with them at her home:

"Kids usually like to play in the backyard. My son's friends do come sometimes, but very rarely. I have one family that come here and no more".

Even though both rarely receive guests at her home, Dewi and Adam claim that they are competent cooks. Adam prepares most of the food while Dewi assists with food serving and cleaning: "My husband is a better cook than me. I don't really have time to cook so he cooks for our family and if the guests are here. Andy and his family cooks for themselves. They have their own fridge and cooking items". 


\section{Case Study 2 Privacy}

Soraya is satisfied with her current two-level townhouse. The split levels allow Soraya and James to have private spaces upstairs without impeding on their house mate's, Jacob, privacy. Notwithstanding, both make sure they spend some time to socialize with Jacob and keep up with current affairs and discuss domestic matters.

"What I like about this home is that it has two bedrooms with two ensuites. That means that we can have our privacy. We are not disturbing each other with our activities, and it's so good because if Jacob comes and goes, we're not getting into each other. But if we want to talk and have a chat, we come downstairs and have dinner together; so it is a very good arrangement and circulation".

Apart from visual privacy between Soraya and Jacob, Soraya is also concerned about visual exposure to adjacent neighbours. Even though Soraya identifies herself as a non-religious Muslim, her Iranian cultural upbringing is the main factor affecting why she is careful about maintaining visual privacy from any external sources:

"I always make sure that my home does not have a view straight into the neighbours because they can see in at night and I don't like that. I'm not very religious person although I grew up in a strict Muslim family. It's more of a psychological effect because our home back in Iran was built very close to next door neighbours. So, I always have this idea that I don't want to be seen by strangers when I'm not fully dressed or in my best look".

\section{Modesty}

Even though Soraya does not wear a hijab, she is still careful about her physical modesty levels to ensure that she wears appropriate clothing when there are guests in her home:

"Actually I don't have the problem with dress modesty. I dress how I am dressed now but I am very careful with what I wear. I am aware about the importance of dress modesty. I think modesty is more of a cultural tradition but that what makes you a stronger and better person physically and mentally".

With regards to design humility, although Soraya admires the simplicity of the design of her current townhouse, she thinks it lacks communal facilities and the townhouse unit lacks a 'homely' feel for the tenants particularly since it is an older townhouse:

"I don't like it to be honest because it makes the tenants and me lonely even though it is a nice simple design. The communal area is badly designed and not very creative. When I look at it, they look like boxes attached together. I think the complex should offer you a lifestyle where you can get to know your neighbours and catch up with them. Your neighbour can be closer than your family because they just live next door. At least there is someone to help in case of an emergency".

The topic with regards to provision for spaces for religious activities was not mentioned by Soraya.

\section{Hospitality}

Most of Soraya's guests are James' friends and they meet up only once a month because their living space can only accommodate a maximum of up to five people, as shown in Figure 7.

"We wish we could have a bigger living room to invite our friends because it is not big enough to entertain them. So, we have to think of where to let them sit. At the moment, we look at our main priorities first, whether we want it for entertainment or to study or what kind of users will be in this home for us. We rented this place for me to study as the first option and the second priority is for cooking and then entertainment as third priority. So far, it's good for five people and it's okay. We try to catch up at restaurants instead".
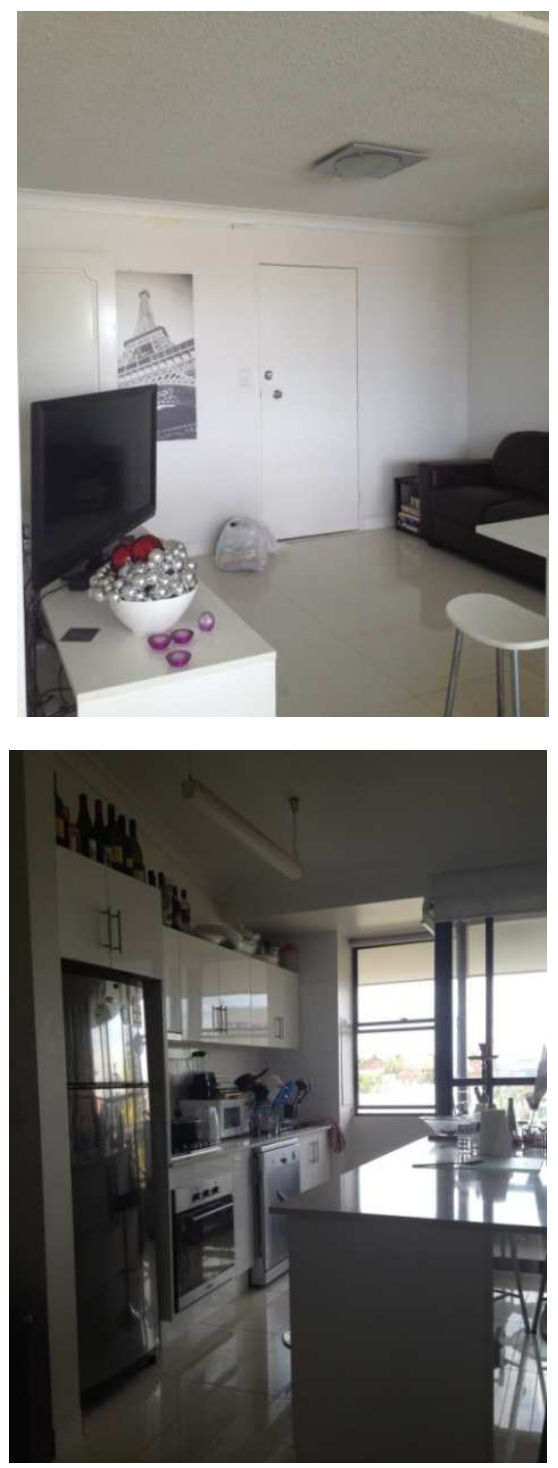

Figure 7. Soraya's kitchen and living area as main hospitality spaces (Source: Zul Othman, Author)

The cooking load is shared among the three of them. Soraya claims that most of the meals cooked are Western food and not Iranian food. This is because James and Jacob are not used to the smell produced from spicy Iranian ingredients:

"I don't really cook Middle Eastern food; I cook mostly Australian western food because of James and my flatmate. So when I start cooking, I'll move to this end section of the kitchen near the window so the smell can 
easily go out. I did once cook Iranian food here and James came down and complained about the smell. So no, I don't cook it after that because I think it would annoy other people in this home".

Hospitality activities in Soraya's homes are limited to quiet conversations with no loud music. This is because her neighbours are very sensitive about levels of noise produced within the townhouse complex:

"We had a party once and my next door neighbour came and knocked on the door and complained about the noise. We don't have problem with other neighbours; they are very friendly and good people. And before he left, he even complained about how we close the door. I went to see the body corporate afterwards and explained about the condition of the door; that it shakes and make noises when we close it".

The townhouse communal area is limited to quiet social activities. This is due to the fact that it is located adjacent to other units on that level. This limits the hospitality and entertainment opportunities for the tenants living in the complex: "I don't really have the opportunities to socialise using the communal area downstairs because it is very small and close to other units. When I was living in Malaysia, I lived in this apartment where they have a very good communal area downstairs and the pool is in the middle. We were able to catch up with friends downstairs and talk about our university work, even during the week and it was very good. Here, everyone will go home and lock the door after $6 \mathrm{pm}$. Over there, you can meet with all people and make new friends. Over here, if it doesn't involve alcohol, you're not one of the mates".

Soraya argues that many multi-storey residential buildings in Brisbane lack communal facilities such as local convenience shops within a complex as compared to apartments in Malaysia, where she used to live.

\section{Case Study 3 \\ Privacy}

Although Farid's home is a compact twobedroom apartment, he is thankful that the bedrooms are separated from the main living room through a corridor, allowing for visual and acoustic privacy:

"The good thing about this apartment is that the rooms are separated from the living area. There is a small corridor that separates them. Only one of the rooms can be seen straight from the corridor. It is nice to make sure you are not visible straight from the living area when you are in the room".

Farid is pleased that the apartment complex is located within a safe neighbourhood even though it is close to the local train station and local pubs: "Actually the most important thing for us is that we live in a place that we know it is safe and no one is going to bother us and we need to be safe especially for women at night. I haven't encountered any problems in terms of security and privacy in this area. We are at higher floor and the trees protect us visually, so that's okay".

\section{Modesty}

Farid considers himself as non-religious Muslim but there are some predominant Iranian cultural customs and traditions that he follows such as removing shoes prior to entering a home. His current apartment, however, does not have any provision for these transition spaces for such tradition:

"There are issues such as spaces to take off your shoes and store them. I think it is lack of design consideration for these issues. The places here are not well designed and thought of in terms of ergonomic studies".

There was no discussion with regards to provision for spaces for religious activities in Farid's apartment.

\section{Hospitality}

Farid emphasised the importance of hospitality in Iranian culture, wherever they are globally. As an Iranian, Farid is proud of his courteous and hospitable behaviours whether in public realm or within his apartment complex:

"The important thing to know is that Iranians are very hospitable. It is quite a different culture here in Australia. Iranians love compliments or courtesy. For example, if you are queuing to get into a lift, we always say "after you" first. It rarely happens here especially among young people".

With regards to extending hospitality within the apartment, Farid claims that there is enough space to entertain limited number of guests (Figures 8), depending on the occasions and types of gatherings. As all of them are students, they converted their dining space into a multi-purpose study area with computer facilities (Figure 8):

"It depends on the community of your friends and how big is your gathering. When I was in the previous apartment, the place was twice as bigger than here. I could invite more people to my place but depends on the occasion. Here, sometimes we just get together for a meal for around eight people. This place is big enough to cater for up to twelve people including ourselves".

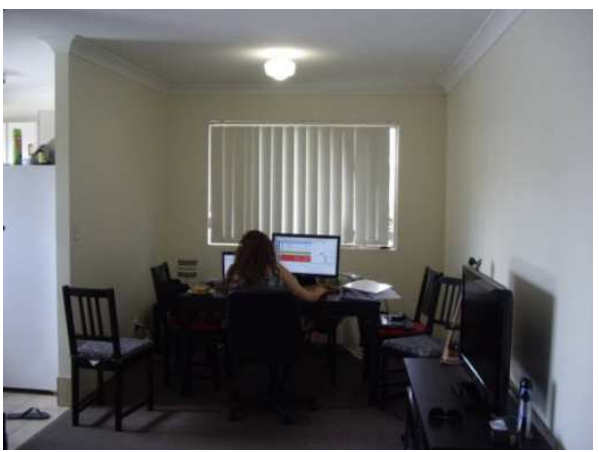

Figure 8. Farid's dining space converted into study area (Source: Zul Othman, Author)

The types of hospitality or entertainment at Farid's apartment are also limited to 'low volume' activities similar to Soraya's townhouse situation. Farid and Ehsan check that their neighbours are informed in advance if they wish to conduct special social occasions such as parties or Eid celebrations: "Actually, we can't make a lot of noise here unless you let your neighbours know. We have an example here for example, a birthday party, recently. There is no body corporate here but I think as long as you inform your 
neighbours and they know that, say, "tonight we may have a louder noise in our apartment", that's okay. But otherwise, they will make a complaint".

\section{Discussion \\ Privacy}

The study provides some early indications of similarities regarding privacy behaviours and traditions among three international Muslim students and their families/spouses in Brisbane. Primary concerns are visual and acoustical privacies between houses and units and the visibility of female members from outside strangers inside the dwellings. All participants experience privacy restrictions inside their homes due to the shared living environment with another housemate or family. As an observant Muslim, Dewi is confronted with the complication of protecting her awrah (intimate parts) when Andy is around at home. She faces similar problem when cooking in the kitchen, worrying that her next door neighbours may look into her kitchen area when the windows are open (Figure 4). Soraya, on the other hand, closes her living room roller shades when she is alone at home to guarantee no outside strangers from other building complexes. Farid is happy with the location of his apartment unit. The unit is located on the top floor (level 3 ) and is visually protected from the streets with help from the shady trees in front of the building complex.

Houses in Brisbane are built to comply with Brisbane City Council's House Code [39] and Australia's National Construction Codes [40]. There are some guidelines for achieving good visual and acoustic privacy in houses and multi-residential dwellings. These privacies are only primarily concerned with the boundaries and external facades of the buildings. It is important for the tenants to carefully plan and use their interior spaces to suit with their privacy requirements. In the case of Dewi's home, for example, it is essential for her to address the matter with her landlord with regards to her kitchen visual privacy dilemma. An intervention of using similar privacy screens at the front windows (Figure 6) or replacing them with frosted glass can resolve this problem. At the same time, Dewi's landlord should be cognizant and well-informed about Muslim's privacy requirements, especially for women, considering that he owns several other homes that he leases to other Indonesian students.

There are different perceptions of privacy between Muslims from the Middle East (Soraya and Farid) and South East Asia (Dewi); which is contradictory to what was found in the literature [23] [33] [35] [36] [37]. This is attributed to the fact that both Soraya and Farid consider themselves to be non-religious Muslims as compared to Dewi, who is a religious and observant Muslim. Nevertheless, all participants agree that their cultural traditions play a stronger role in how they use their domestic spaces, while Islamic teachings are vital for them as guidance for their domestic behaviours and perceptions.

\section{Modesty}

All participants agree that modesty is very important in their lives as Muslims and Islamic cultural teachings pose significant impacts to their domestic behaviours and use of spaces. All participants maintain their behavioural modesty while their housemates or guests are around the house. As a devout Muslim, Dewi is very concerned with maintaining her dress modesty and ensuring that her awrah is protected, especially when Andy is in the house (even when he is in his bedroom). This restricts her from taking off her hijab (veil) even when she is cooking and preparing the meals for the family. Soraya makes sure that she dresses appropriately and does not wear revealing clothing when Jacob or other guests are around. Most of the time, when James' Australian friends are around, Soraya will proceed upstairs to her private living area and this allows James and his friends to socialise while she continues with her university studies. As a Muslim male, Farid is less worried about his awrah. The awrah for a Muslim man is from the navel to the knee; while the awrah for Muslim women is the entire body except for face and hands [30]. All participants accept that design humility is an important architectural design approach. Dewi, Soraya and Farid are research students from a School of Design and they appreciate simple and minimalistic design approaches rather than excessive ornamentations. Squandering in domestic interior decorations is against Islamic modesty principles in terms of the built environment [21] [22]. The issue with regards to spaces for religious activities was only discussed and mentioned by Dewi. Dewi is limited to reciting or listening to Quran at lower volume in her bedroom when Andy and his family are in the house. This is to ascertain that they are comfortable within their own home environment, even though it may not be an issue for them.

\section{Hospitality}

In spite of coming from different cultural backgrounds, there are some similarities in terms of hospitality behavioural patterns and areas where guest entertainment occurs. All participants highlight the limitations of these activities to their living spaces and only with a very limited number of guests at each occasion. This is a common issue among all tenants living in shared homes, townhouses or apartment units. Both Soraya and Farid address the problem of receiving noise complaints from sensitive neighbours if the noise penetrates into their apartment units. There were no definite demarcations between male and female spaces in all participants' homes. Dewi's home, for example, is restricted to the living room for guests and predominantly the backyard for her children's friends (Figure 6). Soraya and Farid do not use their balconies for additional areas for hospitality because they are aware of the noise 
transmission to other units and the possibilities of receiving complaints from their neighbours. Both criticise the badly designed communal spaces within the building complexes, which are the main factors why tenants rarely socialise and make effort to know each other. Soraya and James spend most of their social gatherings with their friends outside their homes, mainly in restaurants or cafes because these venues offer them better opportunities to catch up with their friends without having to worry about noise complaints. Extending hospitality is one of the foundations for social strength and solidarity with your neighbours, friends and extended families [21] [22] [27]. However many of the current townhouse and apartment designs provide much smaller livings areas and no transition spaces between public and private spaces, resulting in noise issues among shared tenants.

\section{Limitations and future directions}

On the whole, this study contributes an introductory insight and understanding of the ways in which three international student families in Brisbane live and use the interior spaces of their homes to comply with their Islamic cultural and religious teachings. Nevertheless, the findings of this study are only established from the three case studies of international Muslim students' homes and cannot be generalised to other Muslim homes around Australia. Future research on the different types of accommodation within different suburbs of Brisbane need to be explored in future to provide a more concrete hypothesis from the findings of this study. This will improve and enrich the data collected from this empirical study with regards to privacy, modesty and hospitality principles based on participants' cultural traditions. A better understanding on the demarcation of public-private zones, hospitality spatial behaviours, the use of spaces for religious activities and other requirements such as the use of shattaf in toilets, will provide useful information for architects, designers and landlords in response to spaces or rooms required for these students.

\section{Conclusion}

The aim of this paper has been to investigate how international Muslim students in Brisbane perceive and achieve privacy, modesty and hospitality within their Australian designed homes, and how these affect their use of domestic spaces, furniture arrangements and satisfaction levels of their current homes, through their lived experiences. Cost of living and affordability are the main factors that determine where they reside while undertaking their studies. All participants are scholarship recipients with very limited monetary funds and they opted for cheaper accommodation in suburban areas that are less expensive to rent than living within Brisbane city centre or close to university campuses. Participants' perceptions of privacy, modesty, hospitality and their use of domestic spaces in their current homes in Brisbane are very different than their homes back in Iran and Indonesia. The shared living situations make it difficult for participants to achieve privacy, perform religious activities or entertain their guests than living in their homes in their countries of origin. Subsequently, participants are less satisfied and comfortable with the conditions of their current homes. Despite having to adapt with Australian culture while maintaining their own cultural traditions, participants managed to concentrate in their studies, perform their daily activities and use this cultural diversity experience to become more inter-culturally competent individuals in the future. More research across Australia could also provide a better analysis and the distribution of international Muslim students in terms of the types of homes and suburbs they prefer to live in. This will enable university accommodation departments or local city councils to provide more detailed and precise information to these students prior to arriving to Australia to continue their higher education regarding the most likely locations where suitable and affordable places for them to live are available.

\section{References}

[1] N. G. Khawaja and J. Dempsey, "A comparison of international and domestic tertiary students in Australia," Australian Journal of Guidance and Counselling, vol. 18, pp. 30-46, 2008.

[2] E. Sawir, "International students and internationalisation of higher education," Journal of International Students, vol. 3, p. III, 2013.

[3] P. Roberts and K. Dunworth, "Staff and student perceptions of support services for international students in higher education: A case study," Journal of Higher Education Policy and Management, vol. 34, pp. 517528, 2012.

[4] G. Harman, "International PhD students in Australian universities: Financial support, course experience and career plans," International Journal of Educational Development, vol. 23, pp. 339-351, 2003.

[5] Department of Immigration and Border Protection, "Student visa programme quarterly report: Quarter ending at 31 March 2014," Australian Government 2014.

[6] M. A. Tarrant, D. L. Rubin, and L. Stoner, "The added value of study abroad: Fostering a global citizenry," Journal of Studies in International Education, vol. 18, pp. 141161, 2014.

[7] C. J. Wynveen, G. T. Kyle, and M. A. Tarrant, "Study Abroad Experiences and Global Citizenship: Fostering Proenvironmental Behavior," Journal of Studies in International Education, vol. 16, pp. 334-352, 2012. 
[8] C. Asmar, "Whose values are valued? Muslim students and the globalised campus," presented at the HERDSA Annual International Conference, Melbourne, Australia, 1999.

[9] L. Sidiropoulos, I. Wex, and J. Sibley, "Supporting the sustainability journey of tertiary international students in Australia," Australian Journal of Environmental Education, vol. 29, pp. 52-79, 2013.

[10] K. W. Dean and M. B. Jendzurski, "Using post-study-abroad experiences to enhance international study," Honors in Practice, vol. 9, p. 99, 2013.

[11] C. Asmar, E. Proude, and L. Inge, "'Unwelcome sisters?' An analysis of findings from a study of how Muslim women (and Muslim men) experience university," Australian Journal of Education, vol. 48, p. 47, 2004.

[12] C. Gomes, M. Berry, B. Alzougool, and S. Chang, "Home away from home: International students and their identitybased social networks in Australia," Journal of International Students, vol. 4, p. 2, 2014.

[13] A. S. Awang-Rozaimie, A. T. Amelia, J. Aiza, S. Siti-Huzaimah, and S. Adib, "Intercultural sensitivity and cross-cultural adjustment among Malaysian students abroad," Journal of Educational and Social Research, vol. 3, p. 693, 2013.

[14] Heathcote, E. (2012). The meaning of home (Illustrated ed.). London: Frances Lincoln Limited.

[15] W. Rybczynski, Home: A short history of an idea. New York, NY: Penguin Books, 1987.

[16] F. Obeng-Odoom, "Far away from home: The housing question and international students in Australia," Journal of Higher Education Policy and Management, vol. 34, pp. 201216, 2012.

[17] E. Sawir, S. Marginson, A. Deumert, C. Nyland, and G. Ramia, "Loneliness and International Students: An Australian Study," Journal of Studies in International Education, vol. 12, pp. 148-180, 2008.

[18] Y. Baek, A. Kanaani, H. Akbar, and G. Baguley, "The needs of Muslim women at QUT," in 24th ISANA International Education Conference Brisbane, Australia, 2013, p. 13.

[19] S. S. Abdullah, "Help seeking behavior among Malaysian international students in Australia," International Journal of Business and Social Science, vol. 2, 2011.

[20] H. Akbar, T. Van Bael, Y. Hassan, and G. Baguley, "Evaluating the QUT homestay program : Lessons learnt in providing quality services to international students," in 15th ISANA International Education Conference, Melbourne, Australia, 2004, p. 13.

[21] H. Mortada, Traditional Islamic principles of built environment. New York (Paperback): RoutledgeCurzon, 2011.
[22] S. Omer, Islam and housing. Kuala Lumpur, Malaysia: A.S. Noordeen, 2010.

[23] A. S. Bahammam, "Architectural patterns of privacy in Saudi Arabian housing," Master of Architecture Electronic Thesis or Dissertation, School of Architecture, McGill University, Montreal, 1987.

[24] K. Al-Kodmany, "Residential visual privacy: traditional and modern architecture and urban design," Journal of Urban Design, vol. 4, pp. 283-311, 1999.

[25] R. Azizah and R. H. Putri, "Implementation of hijab concept in Arab house Pasar Kliwon Surakarta," Journal of Islamic Architecture, vol. 2, 2013.

[26] Y. H. Wazeri, "Comparative study between three courtyards of traditional houses in Islamic Cairo," Journal of Islamic Architecture, vol. 2, pp. 171-179, 2013.

[27] R. Sobh, R. W. Belk, and J. A. J. Wilson, "Islamic Arab hospitality and multiculturalism," Marketing Theory, vol. 13, pp. 443-463, 2013.

[28] C. Asmar, "Politicising student difference: The Muslim experience," in International Relations, Lancaster University, UK, 2005, pp. 129-157.

[29] S. X. Chen, M. H. Bond, B. Chan, D. Tang, and E. E. Buchtel, "Behavioral manifestations of modesty," Journal of Cross-Cultural Psychology, vol. 40, pp. 603626, 2009.

[30] A. W. Boulanouar, "The notion of modesty in Muslim women's clothing: an Islamic point of view," New Zealand Journal of Asian Studies, vol. 8, pp. 134-156, December, 20062006.

[31] R. Sobh and R. Belk, "Domains of privacy and hospitality in Arab Gulf homes," Journal of Islamic Marketing, vol. 2, pp. 125-137, 2011.

[32] J. Derrida, "The principle of hospitality," Parallax, vol. 11, pp. 6-9, 2005.

[33] J. Y. Lim, The Malay house: rediscovering Malaysia's indigenous shelter system. [Pinang], Pulau Pinang, Malaysia: Institut Masyarakat, 1987.

[34] W. H. Wan Teh and A. H. Nasir, The traditional Malay house, Fourth ed. Shah Alam, Malaysia: Penerbit Fajar Bakti, 2011.

[35] J. Sartoni. (2012, 24.10.2014). Traditional architecture of Indonesia Available: http://juliesartoni.blogspot.com.au/2012/0 $3 /$ traditional-architecture-of-indonesia.html

[36] R. Schefold and P. J. M. Nas, Indonesian houses volume 2: Survey of vernacular architecture in western Indonesia vol. 2. Leiden, The Netherlands: KITLV Press, 2008.

[37] S. M. S. Ismail. (2011, 24.10.2014). The traditional Acehnese house. Available: http: //sazalimerci.wordpress.com/2011/11 /25/the-traditional-acehnese-house/ 
[38] Australian Bureau of Statistics. (2011, 21 June). Reflecting a nation: stories from the 2011 Census. Available: http://www.abs.gov.au/ausstats/abs@.nsf/ Lookup/2071.0main+features902012-2013

[39] Brisbane City Council. (2000). Brisbane City Plan: Residential Design-House Code [pdf].
Available:

http://www.brisbane.qld.gov.au/sites/defa ult/files/chapter5_house_code.pdf

[40] Australian Building Codes Board, National Construction Code series 2014. Canberra: ABCB, 2014. 